\title{
Label-free proteomic methodology for the analysis of human kidney stone matrix composition
}

\author{
Frank A. Witzmann ${ }^{1 *}$, Andrew P. Evan², Fredric L. Coe ${ }^{3}$, Elaine M. Worcester ${ }^{3}$, James E. Lingeman ${ }^{4}$ \\ and James C. Williams $\mathrm{Jr}^{2}$
}

\begin{abstract}
Background: Kidney stone matrix protein composition is an important yet poorly understood aspect of nephrolithiasis. We hypothesized that this proteome is considerably more complex than previous reports have indicated and that comprehensive proteomic profiling of the kidney stone matrix may demonstrate relevant constitutive differences between stones. We have analyzed the matrices of two unique human calcium oxalate stones ( $\mathrm{CaOx}-\mathrm{la}$ and $\mathrm{CaOx}$-ld) using a simple but effective chaotropic reducing solution for extraction/solubilization combined with label-free quantitative mass spectrometry to generate a comprehensive profile of their proteomes, including physicochemical and bioinformatic analysis.'
\end{abstract}

Results: We identified and quantified 1,059 unique protein database entries in the two human kidney stone samples, revealing a more complex proteome than previously reported. Protein composition reflects a common range of proteins related to immune response, inflammation, injury, and tissue repair, along with a more diverse set of proteins unique to each stone.

Conclusion: The use of a simple chaotropic reducing solution and moderate sonication for extraction and solubilization of kidney stone powders combined with label-free quantitative mass spectrometry has yielded the most comprehensive list to date of the proteins that constitute the human kidney stone proteome.

Keywords: Calcium oxalate, Kidney stone, Label-free quantitative liquid chromatography-tandem mass spectrometry, Matrix protein, Nephrolithiasis, Proteomics

\section{Background}

The organic matrix within urinary stones has long been thought to be an important-if poorly understood-part of stone composition. It has been proposed that the process of stone formation involves the primary deposition of matrix, with crystal formation occurring secondarily within the matrix layer $[1,2]$. Others maintain that crystallization is primary and that most, if not all, of the organics in stones are co-precipitated with the crystals in a manner that is in no way causative [3]. Recent work on the interface of the growth of calcium oxalate $(\mathrm{CaOx})$ stones on Randall's plaque has suggested that matrix

\footnotetext{
* Correspondence: fwitzman@iu.edu

${ }^{1}$ Department of Cellular and Integrative Physiology, Indiana University School of Medicine, 635 Barnhill Drive, Room 362A, Indianapolis, IN 46202-5120, USA Full list of author information is available at the end of the article
}

deposition is the primary event, at least in the formation of $\mathrm{CaOx}$ stones over plaque. The first layer covering plaque that has been exposed to urine is an organic layer that contains Tamm Horsfall protein, aka uromodulin [4]. Thereafter, nucleation of apatite begins and deposition of $\mathrm{CaOx}$ follows [4].

Progress on characterizing the composition of stone matrix has been slow, in part because of its insolubility. The work that has been done also has demonstrated that the matrix composition is remarkably variable and complex [5]. However, recent studies of human stone matrix have begun to exploit the power of modern proteomic methods, with some patterns beginning to emerge in the kinds of proteins found [6-17]. Nine of these recent stone proteomic studies contain profiles of $\mathrm{CaOx}$ stone- 
or crystal-associated proteins $[6,7,9,11-15,17]$ but only one study has attempted to quantify them [17].

Thus far, the number of proteins identified in human stone matrices has been relatively modest, ranging from 30 [11] to 242 [10] distinct proteins identified across a variety of stone mineral types where the proteome has been investigated. In general, where protein profiles of different types of stones were compared, differences across stone types were minimal whereas protein differences within stone types were quite variable. This is likely due to two factors: 1) only the most abundant, common proteins were identified by these studies and 2) individual kidney stone proteomes are by nature variable and diverse.

We hypothesized that the analysis of human stone matrix should yield significantly more proteins than previously detected and that an improved approach may be useful in studying nephrolithiasis. Using a simple but effective chaotropic reducing solution for extraction and solubilization, one that historically works well for a broad range of protein samples [18-20], combined with gentle, intermittent sonication, we have analyzed extracts of two unique human $\mathrm{CaOx}$ stones, $\mathrm{CaOx}$-Ia and $\mathrm{CaOx}-\mathrm{Id}$, (of different morphologies of $\mathrm{CaOx}$ monohydrate, according to the morphoconstitutional classification scheme published by Daudon [21]), using an established label-free quantitative mass spectrometric (LFQMS) method. This method described in detail elsewhere $[22,23]$ uses individual three-dimensional alignment to determine peptide retention time using a clustering method along with peptide ion peak areas calculated from the extracted ion chromatogram (XIC) generated by liquid chromatography - tandem mass spectrometry (LC-MS/MS). Only two stone matrices were analyzed in this study, by design. Our intent was to 1) improve and simplify the extraction of protein from the stone powder and 2) apply a novel, more comprehensive LFQMS approach to identify and quantify as many proteins as possible. The results indicate a stone matrix proteome that is much larger and more complex than previously observed.

\section{Results and discussion}

\section{Stone extracts}

It is not exactly clear what fraction of the total stone protein can be extracted in a form usable for proteomic analysis. Our extraction method yielded $7.20 \mu \mathrm{g}$ protein $/ \mathrm{mg}$ stone powder for $\mathrm{CaOx}-\mathrm{Ia}$ and $0.81 \mu \mathrm{g} / \mathrm{mg}$ for $\mathrm{CaOx}-\mathrm{Id}$. The larger value is 3 times the average extraction yield that we have previously reported for calcium oxalate monohydrate (COM) stones using $9 \mathrm{M}$ urea/1 mM DTT [5]. The increased amount of protein in $\mathrm{CaOx}$-Ia was likely due to the presence of the $\mathrm{x}$-ray lucent material identified by micro CT. Note that most researchers, not using micro CT, would likely be unable to detect the presence of such a non-mineral-rich material, which, in this case, clung tightly to the surface of stone fragments. On the other hand, protein extraction from specimen $\mathrm{CaOx}$-Id yielded a value within the range we found previously for different COM stone specimens [5], though on the low end of that range. The low yield of protein in this specimen might be related to the tightly packed nature of this form of COM stone (Fig. 1d).

The total amount of protein in these types of stones, estimated from complete acid hydrolysis and measurement of amino acids, has been reported to be about $17 \mu \mathrm{g} / \mathrm{mg}$ [2], but of course, such an acid hydrolysis destroys protein identities. It is likely that a considerable amount of stone protein is resistant to extraction by solubilization methods that maintain protein primary structure, as has been previously reported [5]. In comparison, of the previous studies where proteomic analysis was used and extracted protein yields reported [7, 9, 17], the average was $1.5 \mu \mathrm{g} / \mathrm{mg}$, probably less than $10 \%$ of the total protein contained within the stones.

Whether the extraction resistant proteins are 1) very low abundance components of the matrix proteome trapped within the crystal matrix $[15,16]$ and thus not detected by conventional means, 2) chemically more hydrophilic and accordingly more avidly bound to crystal surfaces, or 3) merely unextracted replicates of the proteins identified below remains to be determined.

\section{Label-free quantitative mass spectrometry}

Using a label-free quantitative mass spectrometry platform, we identified and quantified 1,059 unique protein database (UniProt, http://www.uniprot.org) entries including splice variants or isoforms (809 unique gene names), in the two human kidney stone samples with a false discovery rate (FDR) of $\leq 0.2 \%$. These proteins are listed in a table in Additional file 1, along with their UniProt identities, gene symbols, protein names, and abundances [22]. As illustrated in Fig. 2, 606 proteins were common to both stone types; 70 proteins were unique to $\mathrm{CaOx}-\mathrm{Ia}$, while 383 proteins were detected only in the $\mathrm{CaOx}$-Id stone powder. Specific peptide information for all identified proteins and protein groups including protein coverage, \# of unique sequences, \# of identified peptides, total \# of identified sequences, is available in the table found in Additional file 2 .

To account for potential bacterial proteins within the stone matrix, the MS data were searched against Corynebacterium, Actinomyces, Lactobacillus jensenii, Streptococcus anginosus, and Staphylococcus epidermidis protein databases. No proteins were identified. This strongly suggests that there is no significant bacterial contribution to the stone matrix proteome in the specimens tested.

Since 2008, twelve papers have been published that described various analyses of human kidney/bladder stone 

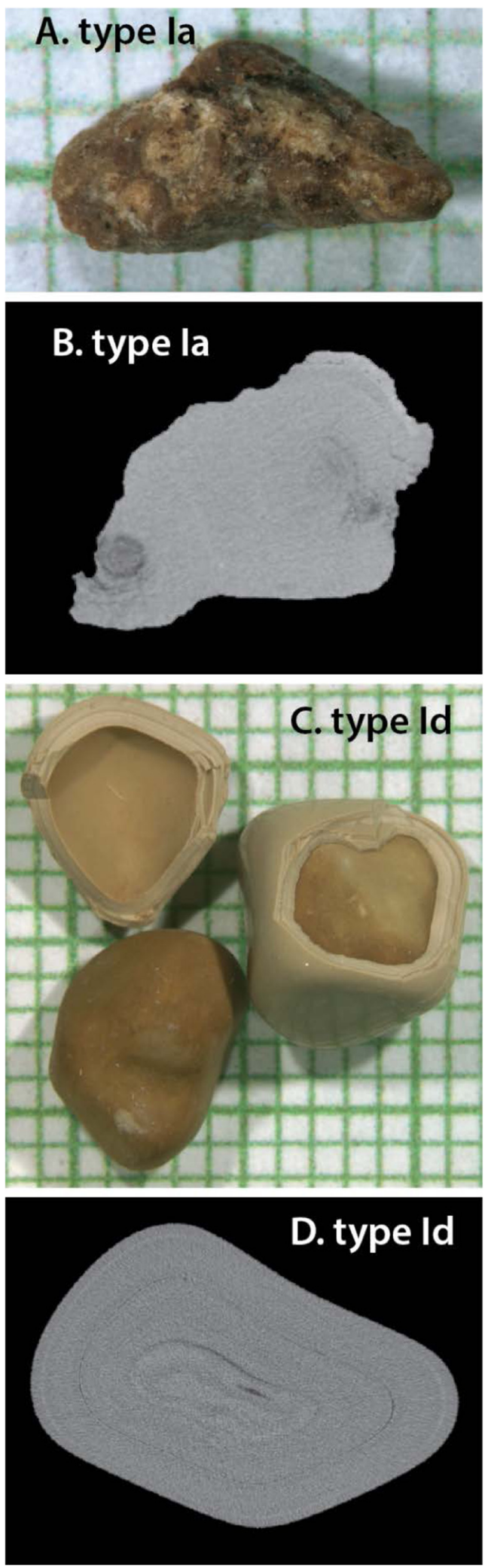

Fig. 1 Representative pieces from the two stone specimens used. a Fragment from CaOx-la, on mm-grid paper. b Micro CT slice through fragment in $\mathrm{A}$, showing pure calcium oxalate monohydrate (COM). c Two stones from specimen $\mathrm{CaOx}$-Id; stone on right has shell broken off to reveal interior core, and on left is shell (top) and core from another stone in this specimen. For $\mathrm{CaOx}-\mathrm{ld}$, only the shell portions were collected for protein extraction. $\mathbf{d}$ Micro CT slice through $\mathrm{CaOx}-\mathrm{ld}$ stone, showing pure COM

matrix proteomes or crystal-associated proteins [6-17]. Compared to those earlier investigations, we found the kidney stone matrix proteome to be larger and much more complex than observed previously. We identified and quantified between 4-35 times as many proteins as found in the other human studies. More specifically, we found 259 proteins that were identified in earlier studies (see the Human Kidney Stone Matrix Proteome Database presented in Additional file 3), and also an additional 577 proteins not identified previously. This database also contains the following information for each protein: isoelectric point ( $\mathrm{pI})$, \# of negatively charged residues (Asp + Glu), \# of positively charged residues (Arg + Lys), Neg/Pos Ratio, aliphatic index, GRAVY score (grand average of hydropathicity), molecular class, biological process, cellular component, and function.

The increased protein identification rate that we achieved in this investigation may be due to two factors. First, several previous studies used a demineralization approach to extract proteins from powdered stones that included EDTA and/or SDS [7-9, 11, 13-17], both of which were subsequently removed by either centrifugation or dialysis steps. Boonla et al. [6] used a commercially available lithium dodecyl sulfate/glycerol solution at $100{ }^{\circ} \mathrm{C}$ to extract proteins. Our use of $8 \mathrm{M}$ urea/10 mM DTT with sonication and two repeated overnight extractions of the stone powder required no additional purification steps

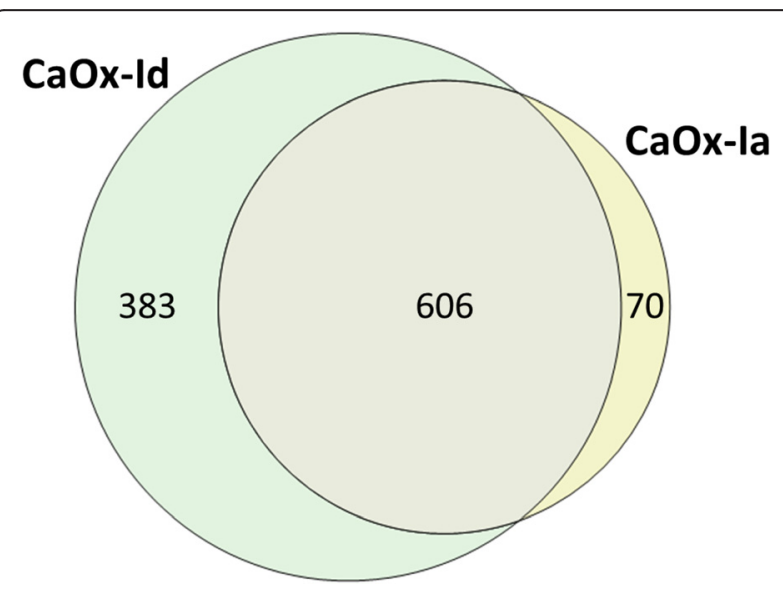

Fig. 2 Venn diagrams showing the degree of overlap and exclusivity of proteins identified and quantified in $\mathrm{CaOx}-\mathrm{la}$ and $\mathrm{CaOx}-\mathrm{ld}$ kidney stone powders 
where proteins might be lost. As mentioned earlier, this approach yielded, on average, more protein/mg of stone powder than in previous studies. But that alone does not account for the differences in the number of proteins detected. A second reason may lie in the protein analysis itself. Several previous studies used 1D and/or 2D gel electrophoresis and subsequent LC-MS/MS or MALDI-MS/ MS to identify proteins in gel plugs $[6,11,13,14,16,17]$. Others used LC-MS/MS or MALDI-MS/MS of whole extracts [7-10, 14-17], but used LC gradient profiles of $60 \mathrm{~min}$ or less to separate the tryptic peptides. Our use of a 190 min LC gradient combined with the rapid scanning features of the Orbitrap Velos Pro mass spectrometer likely underlie our increased protein identification rate. It should be noted that in a proteomic analysis of rat urinary melamine stone matrix (where urea, thiourea, detergent and DTT were used to extract proteins, a $90 \mathrm{~min}$ LC gradient and a high resolution Orbitrap mass spectrometer were used to separate and analyze tryptic peptides), over 1,000 proteins were identified [24].

Interestingly, there are 204 proteins listed in the database in Additional file 3 that were identified in the previous twelve studies, but were not detected in our stone samples. Nearly half of these are accounted for by 96 proteins (of 242) identified by Jou et al. in uric acid stones [10]. The other 146 uric acid stone proteins they detected were also identified in our $\mathrm{CaOx}$ stones. This substantial dissimilarity likely is due to the physicochemical differences between these various stone types and the extraction methods and analytical approaches used. Additionally, Merchant et al. analyzed the proteome of $\mathrm{CaOx}$ stones obtained from human subjects and identified 158 proteins [14]. Forty-five of these were not detected in our $\mathrm{CaOx}$ stones, suggesting that even within similar stone types, the protein composition may be patient-specific and thus differ significantly.

A brief, non-statistical comparison of $\mathrm{CaOx}-\mathrm{Ia}$ and $\mathrm{CaOx}$-Id stone matrix protein composition is presented below. At this point, it is important to restate that only two stone matrices were analyzed in this study, by design, and that our intent was to 1) improve and simplify the extraction of protein from the stone powder and 2) apply a novel, more comprehensive LFQMS approach to identify and quantify as many proteins as possible. The following data analysis is by no means intended to imply the existence of significant differences between the unique $\mathrm{CaOx}$ stones. It is presented here to compare and contrast the results of our new quantitative approach to previous stone matrix proteome studies and not to make inferences on the pathophysiology of $\mathrm{CaOx}$ stone formation.

The 50 most abundant proteins from each stone are listed in Table 1. These correspond to many of the proteins reported in previous studies, in particular: serum albumin, apolipoproteins, calgranulins, osteopontins (10-12-fold higher in $\mathrm{CaOx}-\mathrm{Id}$ ), prothrombin, alpha and beta hemoglobin, neutrophil defensin I, complement proteins, and alpha-1-antitrypsin. In contrast, proteins such as fatty acid synthase and numerous cytokeratins were rarely observed in previous studies. Their absence from previous studies may be accounted for by the fact that these proteins were not disclosed as their occurrence is generally thought to be due to contamination from skin and ambient environment. This may be true of the epidermal and cuticular keratins identified in this study (KRT2, KRT10, KRT31, KRT77, KRT81 KRT84, KRT85), while others are wellestablished components of epithelial cells throughout the kidney [25-27] (KRT1, KRT3, KRT5, KRT6, KRT7, KRT8, KRT9, KRT13, KRT14, KRT17, KRT18, KRT19, KRT31, KRT80).

When one examines the database in Additional file 3, of the 257 proteins reported in other papers that also were found in our study, albumin, uromodulin (TammHorsfall Protein, THP), calgranulin-A (Protein S100-A8), and calgranulin-B (Protein S100-A9) were common to all studies. Albumin and THP were similarly abundant in both our $\mathrm{CaOx}$ stones while calgranulin-A was nearly ten-fold higher in $\mathrm{CaOx}$-Ia. Lactotransferrin, osteopontin, and prothrombin were detected in ten previous studies and Vitamin $\mathrm{K}$-dependent protein $\mathrm{Z}$ was detected in nine. Twenty-two immunoglobulin-related proteins and 28 complement-related proteins were identified and quantified, and most were common to both of our $\mathrm{CaOx}$ specimens.

Note that many of the proteins listed are undoubtedly from blood or tissue, but this is also true for proteins found in human urine [28]. Some work that has been done on crystallization of calcium oxalate crystals in vitro in human urine has suggested that proteins of blood and tissue are not adsorbed to forming crystals, with the idea that proteins of the blood or tissue are not relevant to stone formation [29]. But simple crystal formation is not the same as the formation of a stone, in which the protein matrix plays an important role [30]. Moreover, injury to the renal papilla may be a normal part of stone formation [31], so the presence of blood and tissue proteins could well be a part of the formation of a true stone.

\section{Physicochemical analysis}

Previous studies have considered the aggregate protein charge and its potential connection to specific stone types $[7,10]$. In a comparison of 4 different stone types, Canales et al. [7] failed to observe statistically significant differences between the number of acidic- versus basicfractionated matrix proteins. In our study (Table 2), the average pI of all proteins associated with the $\mathrm{CaOx}$-Ia stone or the $\mathrm{CaOx}$-Id stone was similar (6.62 vs. 6.49), 
Table 1 Fifty most-abundant proteins in kidney stones CaOx-la and $\mathrm{CaOx}-\mathrm{Id}$

\begin{tabular}{|c|c|}
\hline $\mathrm{CaOx-la}$ & $\mathrm{CaOx}-\mathrm{Id}$ \\
\hline Hemoglobin subunit beta & Prothrombin \\
\hline $\begin{array}{l}\text { Neutrophil defensin } 1 \\
\text { (Defensin, Alpha 1) }\end{array}$ & Hemoglobin subunit beta \\
\hline Hemoglobin subunit alpha & Hemoglobin subunit alpha \\
\hline Protein S100-A9 (Calgranulin-B) & Thrombin light chain \\
\hline Complement C3 & Vitronectin \\
\hline Hemoglobin subunit delta & Complement C3 \\
\hline Protein S100-A8 (Calgranulin-A) & Vitamin K-dependent protein Z \\
\hline Alpha-1-antitrypsin & Plasminogen \\
\hline Keratin, type I cytoskeletal 10 & Keratin, type I cytoskeletal 10 \\
\hline Prothrombin & Serum albumin \\
\hline Fibrinogen beta chain & Hemoglobin subunit delta \\
\hline ATP-dependent RNA helicase A & C4b-binding protein alpha chain \\
\hline Apolipoprotein A-IV & Alpha-1-antitrypsin \\
\hline Keratin, type I cytoskeletal 13 & Keratin, type II cytoskeletal 1 \\
\hline Serum albumin & Fatty acid synthase \\
\hline Keratin, type II cytoskeletal 1 & Apolipoprotein A-I \\
\hline Keratin, type I cytoskeletal 9 & $\begin{array}{l}\text { Mannan-binding lectin serine } \\
\text { protease } 2\end{array}$ \\
\hline Fatty acid synthase & Osteopontin, Isoform 5 \\
\hline Nucleolin & Myosin-9 \\
\hline Apolipoprotein B-100 & Heat shock protein beta-1 \\
\hline Heparin cofactor 2 & Fibroleukin (fibrinogen-like 2) \\
\hline Actin, cytoplasmic 1 & Apolipoprotein D \\
\hline Fibrinogen alpha chain & Histidine-rich glycoprotein \\
\hline Plasminogen & Tubulin beta chain \\
\hline Profilin-1 & Fibrinogen beta chain \\
\hline Eosinophil cationic protein & Kininogen-1, Isoform LMW \\
\hline Coagulation factor XII & Keratin, type I cytoskeletal 9 \\
\hline Complement C4-A & Heat shock protein HSP 90-beta \\
\hline Complement C4-B & Apolipoprotein B-100 \\
\hline Vitronectin & Pro-epidermal growth factor \\
\hline Myosin-9 & Fibrinogen alpha chain \\
\hline Apolipoprotein A-I & $\begin{array}{l}\text { Neutrophil defensin } 1 \\
\text { (Defensin, Alpha 1) }\end{array}$ \\
\hline Leukocyte elastase inhibitor & $\begin{array}{l}\text { Extracellular superoxide dismutase } \\
\text { [Cu-Zn] }\end{array}$ \\
\hline Alpha-2-macroglobulin & Argininosuccinate synthase \\
\hline Apolipoprotein D & Heparin cofactor 2 \\
\hline Thrombin light chain & Complement factor B \\
\hline Complement factor B & Keratin, type I cytoskeletal 19 \\
\hline Histone $\mathrm{H} 4$ & Apolipoprotein A-IV \\
\hline $\begin{array}{l}\text { Vesicular integral-membrane } \\
\text { protein VIP36 }\end{array}$ & Complement C4-A \\
\hline Fibrinogen gamma chain & Coagulation factor $X$ \\
\hline
\end{tabular}

Table 1 Fifty most-abundant proteins in kidney stones CaOx-la and $\mathrm{CaOx}-\mathrm{Id}$ (Continued)

\begin{tabular}{|c|c|}
\hline Serum paraoxonase/arylesterase 1 & Complement C4-B \\
\hline Peroxiredoxin-2 & $\begin{array}{l}\text { Vesicular integral-membrane } \\
\text { protein VIP36 }\end{array}$ \\
\hline Complement C5 & Actin, cytoplasmic 1 \\
\hline Complement component C9 & Profilin-1 \\
\hline WD repeat-containing protein 1 & Nucleolin \\
\hline Antithrombin-III & Keratin, type II cytoskeletal 7 \\
\hline $\begin{array}{l}\text { Mannan-binding lectin serine } \\
\text { protease } 2\end{array}$ & Protein S100-A9 (Calgranulin-B) \\
\hline $\begin{array}{l}\text { Mannosyl-oligosaccharide } \\
\text { 1,2-alpha-mannosidase IA }\end{array}$ & Osteopontin, Isoform B \\
\hline Vitamin K-dependent protein S & $\begin{array}{l}\text { Mannosyl-oligosaccharide } \\
\text { 1,2-alpha-mannosidase IA }\end{array}$ \\
\hline Keratin, type II cytoskeletal 2 & Antithrombin-III \\
\hline
\end{tabular}

Proteins listed in order of abundance

as was the average $\mathrm{pI}$ of all proteins unique to $\mathrm{CaOx}$-Ia or $\mathrm{CaOx}$-Id stones (6.75 vs. 6.33). In comparison, a slightly more alkaline average $\mathrm{pI}$ of 7.2 has been observed in uric acid stone matrix proteins [10]. Conclusive comparison of these and other properties requires additional samples and further study. Nevertheless, negative amino acid/positive amino acid ratios, aliphatic indices (a measure of protein stability) and GRAVY scores were similar across all comparisons in the $\mathrm{CaOx}$ stones. The mean GRAVY scores, all considerably negative, indicate overall protein hydrophilicity.

\section{Bioinformatic analysis}

Of the proteins listed in the Human Kidney Stone Matrix Proteome Database (Additional file 3), 680 (82\%) have been detected in kidney cells or tissue (per the Human Proteome Map), 154 (18 \%) have not been detected in kidney, so their origin may be considered "extra-renal", 144 (17\%) are considered to be moderately or highly abundant in kidney, 248 (30 \%) are considered to be in the "extracellular component" (kidney or otherwise), and 75 (9\%) are considered to be "cytoskeletal and/or structural" proteins.

Proteins identified in the $\mathrm{CaOx}$ stones also represented a broad variety of molecular classes (Table 3 ). The distribution of classes reflects the prevalence of "cellular proteins" in the matrix, dominated by cytoskeletal \& associated proteins, structural proteins, transport/cargo proteins, chaperone/heat shock proteins, and ribonucleoprotein/RNA binding proteins, rather than an excess of urine- or plasma-related proteins. Many of these proteins may stem from the considerable cellular components of stone matrices first observed by Boyce in 1956 [32]. Nevertheless, as Table 1 and Additional file 1 indicate, the individually most abundant proteins in the 
Table 2 Physicochemical characteristics of stone matrix proteomes

\begin{tabular}{lllll}
\hline & Isoelectric Point & Neg/Pos Ratio & Aliphatic Index & GRAVY Score \\
\hline CaOx-la All Proteins & $6.62 \pm 1.65$ & $1.16 \pm 0.66$ & $79.07 \pm 11.17$ & $-0.416 \pm 0.229$ \\
CaOx-Id All Proteins & $6.49 \pm 1.65$ & $1.19 \pm 0.60$ & $78.92 \pm 11.42$ & $-0.438 \pm 0.240$ \\
CaOx-la Only & $6.75 \pm 1.71$ & $1.08 \pm 0.39$ & $80.14 \pm 12.26$ & $-0.340 \pm 0.171$ \\
CaOx-Id Only & $6.33 \pm 1.65$ & $1.20 \pm 0.39$ & $78.97 \pm 15.16$ & $-0.458 \pm 0.348$ \\
\hline
\end{tabular}

$\mathrm{CaOx}$ stone matrix are blood/plasma derived - and presumably urine - proteins.

The following calcium binding proteins were detected: annexins A1, A2, A3, A4, A5, A9, A10, and A11; calcyphosin; calmodulin; calsequestrin-2; cilaggrin-2; cucle obindin-1; osteopontin; Profilaggrin; Protein S100-A2 (S100 calcium-binding protein A2); Protein S100-A6 (Calcyclin); Protein S100-A7 (Psoriasin); Protein S100A8 (Calgranulin-A); Protein S100-A9 (Calgranulin-B); Protein S100-P (Migration-inducing gene 9 protein); Protein S100-A11 (Calgizzarin); and Protein S100-A12 (Calgranulin-C), and these may have implications in the mineralization process $[33,34]$. Additionally, the following urinary proteins known to have the potential to modulate crystal formation and retention [35-37] were identified and quantified as prominent constituents of the stone matrix: Tamm-Horsfall protein; osteopontin; A-1 microglobulin; calprotectin (protein S100-A8 \& 9); serum albumin; prothrombin; inter- $\alpha$ trypsin inhibitor (heavy chains $\mathrm{H} 1, \mathrm{H} 2$, and 4); heparin sulphate proteoglycan; bikunin; CD44, fetuin, and various collagens.

As in two previous studies $[10,14]$ where inflammatory, coagulation, cell adhesion, and acute-phase response pathways were directly related to high abundance matrix proteins, we used pathway analysis to predict with statistical confidence which pathways might be associated with the matrix proteins identified and quantified in our $\mathrm{CaOx}$ stones. These results (79 unique pathways) are presented in the Pathway Data found in Additional file 4. Some of the most statistically significant pathways included LXR/ RXR activation, coagulation system, acute phase response signaling, FXR/RXR activation, clathrin-mediated endocytosis signaling, intrinsic prothrombin activation pathway, epithelial adherens junction signaling/remodeling, extrinsic prothrombin activation, complement system, and the production of nitric oxide and reactive oxygen species in macrophages. Analogous observations were made via functional annotation clustering of the $\mathrm{CaOx}$ proteins presented in the Functional Annotation Clusters found in Additional file 5, where inflammatory response and immune related functions were most notable and cytoskeletal structural molecule activity, extracellular glycoprotein signaling, wound healing, coagulation, and regulation of body fluid levels annotations were significantly represented.

\section{Conclusions}

The proteomic data presented here corroborate and significantly expand previous observations of the kidney stone matrix protein composition, revealing a more complex matrix proteome than previously reported for human kidney stones of any type. It remains unclear as to whether the identified proteins, their physicochemical properties, and their associated pathways/functions are directly related to mechanisms of stone formation or simply coincident and accumulated through long-term exposure of the growing stone to urine flow. Nonetheless, the comprehensive approach we have developed and reported here will enable us and others to address such questions by analyzing and comparing comprehensive protein profiles in a broad range of stone types in relatively small stone specimens from individual patients who are carefully stratified by phenotype, and for whom important clinical data are known.

\section{Methods \\ Reagents}

Urea, DL-Dithiothreitol (DTT), triethylphosphine (TEP), iodoethanol, and ammonium bicarbonate $\left(\mathrm{NH}_{4} \mathrm{HCO}_{3}\right)$ were purchased from Sigma-Aldrich (St. Louis, MO, USA). LC-MS grade acetonitrile (ACN) with $0.1 \%$ formic acid $(\mathrm{v} / \mathrm{v})$ and water $\left(\mathrm{H}_{2} \mathrm{O}\right)$ with $0.1 \%$ formic acid $(\mathrm{v} / \mathrm{v})$ were purchased from Burdick \& Jackson (Muskegon, MI, USA). Modified sequencing grade porcine trypsin was obtained from Princeton Separations (Freehold, NJ, USA). All other reagents used were of the highest quality available.

\section{Stone specimens, preparation of stone matrix protein extracts, and protein assay}

Stones were de-identified specimens analyzed as pure $\mathrm{COM}$ and obtained from a stone analysis laboratory (Beck Analytical Services, Indianapolis IN). They were chosen so that several grams of material were available within a single specimen. The specimens were scanned using micro CT (SkyScan 1172, Bruker, Kontich, Belgium) to assess overall mineral purity, and mineral composition was confirmed using Fourier-transform infrared spectroscopy [38].

Figure 1 shows representatives of the two specimens used in the present study. The specimen named $\mathrm{CaOx}$-Ia consisted of multiple fragments of COM that mostly had the morphological form Ia, which indicates a tightly 
Table 3 Representation of $\mathrm{CaOx}$ stone proteins by molecular class ( $\geq 5)$

\begin{tabular}{|c|c|}
\hline Protein Molecular Class & $\begin{array}{l}\text { \# of unique proteins } \\
\text { identified }\end{array}$ \\
\hline $\begin{array}{l}\text { Cytoskeletal \& associated protein; structural } \\
\text { protein }\end{array}$ & 75 \\
\hline Transport/cargo protein & 49 \\
\hline Chaperone/Heat shock protein & 36 \\
\hline Ribonucleoprotein; RNA binding protein & 35 \\
\hline Extracellular matrix protein & 31 \\
\hline Transcription factor or regulatory protein & 29 \\
\hline Enzyme: Hydrolase & 27 \\
\hline Translation regulatory protein & 27 \\
\hline G protein; GTPase \& associated & 26 \\
\hline Immunoglobulin & 24 \\
\hline Unclassified & 24 \\
\hline Ribosomal subunit & 23 \\
\hline Adhesion molecule & 21 \\
\hline Enzyme: dehydrogenase & 21 \\
\hline Ubiquitin proteasome system & 21 \\
\hline Complement protein & 20 \\
\hline Protease inhibitor & 19 \\
\hline Adapter molecule & 18 \\
\hline Calcium binding protein & 18 \\
\hline Secreted polypeptide & 18 \\
\hline Coagulation factor & 16 \\
\hline Cysteine protease & 15 \\
\hline DNA binding protein & 15 \\
\hline Integral membrane protein & 15 \\
\hline Serine/threonine kinase or phosphatase & 15 \\
\hline Enzyme: Ligase & 14 \\
\hline Enzyme: Oxidoreductase & 14 \\
\hline Cell surface receptor & 12 \\
\hline Enzyme: Phosphotransferase & 12 \\
\hline Serine protease & 9 \\
\hline Enzyme: Isomerase & 7 \\
\hline Enzyme: Peroxidase & 6 \\
\hline Membrane transport protein & 6 \\
\hline MHC complex protein & 6 \\
\hline ATPase & 5 \\
\hline Enzyme: Reductase & 5 \\
\hline
\end{tabular}

packed COM form that typically is dark brown in color [21]. The CaOx-Ia specimen also contained some $\mathrm{x}$-ray lucent material, identified by infrared spectroscopy to be non-mineralized protein. Specimen $\mathrm{CaOx}$-Id was also pure COM, but consisted of a dozen smooth stones of the morphological form Id, a distinctly different but still tightly packed form of COM [21]. Note that CaOx-Id, due to its morphology, contained no extraneous protein, as did $\mathrm{CaOx}$-Ia. It may also be noteworthy that neither of these $\mathrm{CaOx}$ specimens contained any apatite that was visible by micro CT (a very sensitive method for detecting this mineral [38]). Thus, these $\mathrm{CaOx}$ specimens were not representative of the kinds of stones that would arise from growth on Randall's plaque [4].

$\mathrm{CaOx}$-Ia and $\mathrm{CaOx}$-Id stones were powdered by hand in small portions using an agate mortar and pestle, grinding the powder to the consistency of fine flour. The portions of powder for each specimen were combined and thoroughly mixed. Aliquots of these stone powders $(300 \mathrm{mg}$ ) were combined with $1 \mathrm{~mL}$ of freshly prepared $8 \mathrm{M}$ urea and $10 \mathrm{mM}$ DTT by vortex mixing (15 s) in Fisherbrand ${ }^{\mathrm{ms}}$ skirted microcentrifuge tubes with threaded ends (Catalog No. 02-681-343). The suspension was sonicated (Microson $^{\mathrm{nt}}$, Misonix, USA) by 10 intermittent $1 \mathrm{~s}$ microprobe pulses at an energy output of $15 \mathrm{~W}$, every $30 \mathrm{~min}$ for $4 \mathrm{~h}$ at room temperature. The tubes were incubated at room temperature overnight on an orbital shaker (200 rpm), vortexed, and subjected to one more sonication step as described above. The suspension was centrifuged at 3,200 $\mathrm{x} \mathrm{g}$ for $1 \mathrm{~h}$ at room temperature (Jouan GR4i centrifuge, ThermoFisher Scientific, USA). The supernatant was collected and the pellet subjected to a second protein extraction carried out exactly as the first. Extracts were combined and protein concentration in each pooled extract $(\sim 2 \mathrm{~mL})$ was determined by the Bradford assay [39]. The solubilized protein extracts were then stored at $-80{ }^{\circ} \mathrm{C}$ until LFQMS analysis.

\section{Proteolysis and LC-MS/MS}

A $100 \mu \mathrm{g}$ aliquot of each sample was concentrated using the Vivaspin 500 Centrifugal Concentrator (Vivaproducts, USA) by centrifugation at $8,000 \mathrm{rpm}$. The volume of each sample was adjusted to $200 \mu \mathrm{L}$ (4 M urea) and then reduced and alkylated by triethylphosphine and iodoethanol as previously described [40]. Briefly, $200 \mu \mathrm{L}$ of the reduction/alkylation cocktail was added to the protein solution. The sample was incubated at $35^{\circ} \mathrm{C}$ for $60 \mathrm{~min}$, dried by a Vacuum Concentrator Centrifugal System (RC 10.10, Jouan), and reconstituted with $100 \mu \mathrm{L}$ of $100 \mathrm{mM}$ $\mathrm{NH}_{4} \mathrm{HCO}_{3}$ at $\mathrm{pH}$ 8.0. A $150 \mu \mathrm{L}$ aliquot of a $20 \mu \mathrm{g} / \mathrm{mL}$ trypsin solution was added to the sample and incubated at $35{ }^{\circ} \mathrm{C}$ for $3 \mathrm{~h}$, after which another $150 \mu \mathrm{L}$ of trypsin was added, and the solution incubated at $35{ }^{\circ} \mathrm{C}$ for an additional $3 \mathrm{~h}$.

Sample digests were analyzed using a ThermoScientific Orbitrap Velos Pro hybrid ion trap-Orbitrap mass spectrometer coupled with a Surveyor autosampler and MS HPLC system (ThermoScientific). Tryptic peptides were injected as technical replicates onto a C18 reversed phase column (TSKgel ODS-100 V, $3 \mu \mathrm{m}, 1.0 \mathrm{~mm} \times 150 \mathrm{~mm}$ ) at 
a flow rate of $50 \mu \mathrm{L} / \mathrm{min}$. The mobile phases $\mathrm{A}, \mathrm{B}$, and $\mathrm{C}$ were $0.1 \%$ formic acid in water, $50 \% \mathrm{ACN}$ with $0.1 \%$ formic acid in water, and $80 \%$ ACN with $0.1 \%$ formic acid in water, respectively. The gradient elution profile was as follows: $10 \% \mathrm{~B}$ (90 \% A) for $7 \mathrm{~min}, 10-67.1 \% \mathrm{~B}$ (90$32.9 \% \mathrm{~A})$ for $163 \mathrm{~min}, 67.1-100 \% \mathrm{~B}(32.9-0 \% \mathrm{~A})$ for $10 \mathrm{~min}$, and $100-50 \% \mathrm{~B}(0-50 \% \mathrm{C})$ for $10 \mathrm{~min}$. It is important to note that the 190 min elution gradient used in this analysis is much longer than conventional 60 min elution profiles used in previous kidney stone proteome studies [7-10, 14-17] where LC-MS/MS was used, and likely accounts for much of the significant improvement in proteome coverage observed here (see Results and Discussion).

The data were collected in the "Data dependent MS/ MS" mode of Fourier transform-ion trap (MS-MS/MS) with the electrospray ionization interface using normalized collision energy of $35 \%$ (collision induced dissociation). Dynamic exclusion settings were set to repeat count $=1$, repeat duration $=30 \mathrm{~s}$, exclusion duration $=$ $45 \mathrm{~s}$, and exclusion mass width $=10 \mathrm{ppm}$ (low) and 10 ppm (high).

\section{Protein Identification and ouantification}

The acquired data were searched against the UniProt protein sequence database of HUMAN (released on 07/09/2014) using X!Tandem algorithms in the TransProteomic Pipeline (TPP, v. 4.6.3) (http://tools.proteomecenter.org/software.php). General parameters were set to: parent monoisotopic mass error set as $10 \mathrm{ppm}$, cleavage semi set as yes, missed cleavage sites set at 2 , and static modification set as $+44.026215 \mathrm{Da}$ on Cysteine. The peptide and protein identifications made by X!Tandem were validated by PeptideProphet [41] and ProteinProphet [42] in the TransProteomic Pipeline (http://tools.proteomecenter.org). Only validated proteins and peptides with protein probability $\geq 0.9000$ and peptide probability $\geq$ 0.8000 were reported. False discovery rate (FDR) was estimated by a nonparametric concatenated randomized target-decoy database search [43]. As mentioned earlier, for this experiment and those TPP settings, protein identification FDR was $\leq 0.2 \%$.

Protein quantity was determined using an in-house label-free quantification software package, IdentiQuantXL [22], developed to individually and accurately align the retention time of each peptide and to apply multiple filters for exclusion of unqualified peptides to enhance label-free protein quantification. As previously described in detail [22], peptide retention time determination using clustering, extraction of peptide intensity using MASIC [44], peptide coefficient of variation calculation, and peptides correlation were all conducted within the software platform to "filter out" unqualified peptides. Using only qualified peptides, protein intensity was calculated using the formula: Protein Intensity $=($ intensity of peptide 1$) /($ peptide 1 sharing times $)+\ldots+$ (intensity of peptide $n) /($ peptide $\mathrm{n}$ sharing times). For a peptide shared by different proteins, the intensity of this peptide was divided by the number of times the peptide was shared.

\section{Validation of protein identity and quantity}

Results of the LFQMS analysis were validated immunologically for beta-2-microglobulin, calbindin, clusterin, cystatin-C, glutathione S-transferase $\mathrm{P}$, neutrophil gelatin ase-associated lipocalin, and osteopontin. CaOx-Ia and $\mathrm{CaOx}$-Id protein extracts were processed on a Bio-Plex 200 System with High Throughput Fluidics (HTF) Multiplex Array System (Bio-Rad Laboratories, Hercules, CA). The proteins were quantified simultaneously using Bio-Plex Pro $^{\mathrm{Tm}}$ RBM Human Kidney Toxicity Assays (panels 1 and 2) on the Bio-Plex 200 system (BIO-RAD, USA) according to manufacturer instructions. Results were compared to LFQMS data as the ratio between $\mathrm{CaOx}-\mathrm{Ia} / \mathrm{CaOx}-\mathrm{Id}$ and these data are listed in Table 4.

\section{Physicochemical properties of matrix proteins}

Grand average of hydropathicity (GRAVY) scores, aliphatic indices, and number of negatively (Asp and Glu) and positively (Arg and Lys) charged residues for all identified proteins were calculated using the Protein Identification and Analysis Tools (ProtParam) on the ExPASy Server (http://web.expasy.org/protparam/) [45]. The GRAVY score for a peptide or protein is calculated as the sum of hydropathy values of all the amino acids, divided by the number of residues in the sequence. The aliphatic index of a protein is defined as the relative volume occupied by aliphatic side chains (alanine, valine, isoleucine, and leucine) and may be regarded as a positive factor for increased thermostability of globular proteins.

\section{Bioinformatic analysis}

To investigate the functional relevance of the proteins identified and quantified in the two stones, we used two common bioinformatic tools. Protein gene-symbol lists were uploaded onto the Ingenuity Pathway Analysis (IPA)

Table 4 Validation of LFQMS Results: CaOx-la/CaOx-ld Ratio

\begin{tabular}{lll}
\hline Protein & LFQMS & ELISA \\
\hline Beta-2-microglobulin & 0.7 & 0.2 \\
Calbindin & $\mathrm{ND}^{\mathrm{a}}$ & $\mathrm{ND}^{\mathrm{a}}$ \\
Clusterin & 0.4 & 0.2 \\
Cystatin-C & 0.1 & 0.4 \\
Glutathione S-transferase P & 0.9 & 0.9 \\
Neutrophil gelatinase-associated lipocalin & $\mathrm{ND}^{\#}$ & 8.5 \\
Osteopontin, Isoform 5 & 0.1 & 0.1 \\
\hline
\end{tabular}

$\mathrm{ND}^{\mathrm{a}}=$ not detected in either stone; $\mathrm{ND}^{\#}=$ not detected in $\mathrm{CaOx}-\mathrm{ld}$ 
software server (http://www.ingenuity.com) (Qiagen, US) and analyzed using the Core Analysis module to rank stone-specific proteins into canonical pathways in a statistically significant manner. Additionally, UniProt identifiers were submitted to the Human Proteome Map (http:// www.humanproteomemap.org) [46], GeneCards (http:// www.genecards.org) [47], and the Gene Ontology (GO) database (http://go.princeton.edu/cgi-bin/GOTermMapper) [48] via Generic Gene Ontology (GO) Term Mapper for information regarding each protein's molecular class, biological process, cellular component, tissue specificity, and function.

\section{Additional files}

Additional file 1: Protein quantitation data for 1,059 human kidney stone proteins. (PDF $418 \mathrm{~kb}$ )

Additional file 2: Peptide sequence/Protein Identification, mass spectral data for 5,957 peptides. (PDF $3099 \mathrm{~kb}$ )

Additional file 3: Human Kidney Stone Matrix Proteome Database 1,039 proteins found in human kidney stone matrices from this study and 12 other proteomic papers. Includes details regarding Isoelectric Point, negatively charged residues (Asp + Glu), positively charged residues (Arg + Lys), Neg/Pos Ratio, Aliphatic index, GRAVY score, Molecular Class, Biological Process, Cellular component, and Function. (PDF 316 kb)

Additional file 4: Ingenuity Pathway Analysis Results - Canonical Pathways associated with Kidney stone matrix proteins. (PDF 60 kb)

Additional file 5: Functional Annotation Clustering of kidney stone matrix proteins obtained from the DAVID database. (PDF $100 \mathrm{~kb}$ )

\section{Abbreviations}

ACN: acetonitrile; $\mathrm{CaOx}$ : calcium oxalate; COM: calcium oxalate monohydrate; CT: computed tomography; DTT: dithiothreitol; EDTA: ethylenediaminetetraacetic acid; GRAVY: grand average of hydropathicity; LC-MS/MS: liquid chromatography tandem mass spectrometry; LFQMS: label-free quantitative mass spectrometry; MALDI-MS/ MS: matrix-assisted laser desorption ionization tandem mass spectrometry; RNA: ribonucleic acid; SDS: sodium dodecyl sulfate; THP: Tamm-Horsfal Protein; TEP: triethylphosphine.

\section{Competing interests}

The authors have no known competing interests either financial or personal between themselves and others that might bias the work.

\section{Authors' contributions}

FW and JW were responsible for the conception of the study and performed sample preparation and analysis; FW was responsible for mass spectrometric analysis; FW and JW performed data analyses and prepared figures and tables. AE and FC reviewed the data for significant proteins and critically reviewed the manuscript. EW oversaw the project, compared the data with proteins suspected to be active in stone formation, provided funding for the project, and critically reviewed the manuscript. J supplied the stone specimens, provided expertise in stone analysis as part of the study, and critically reviewed the manuscript. All authors wrote or contributed to the writing of the manuscript and approved the final version.

\section{Acknowledgements}

This project was supported by NIH grant P01 DK-56788. The authors appreciatively acknowledge the technical assistance of Dr. Xianyin Lai and Mrs. Guihong Qi in the mass spectrometric analysis.

\section{Author details}

'Department of Cellular and Integrative Physiology, Indiana University School of Medicine, 635 Barnhill Drive, Room 362A, Indianapolis, IN 46202-5120, USA. ${ }^{2}$ Department of Anatomy and Cell Biology, Indiana University School of Medicine, Indianapolis, IN, USA. 'Department of Medicine, Nephrology Section, University of Chicago, Chicago, IL, USA. ${ }^{4}$ International Kidney Stone Institute, Methodist Hospital, Indianapolis, IN, USA.

Received: 25 November 2015 Accepted: 19 February 2016

Published online: 27 February 2016

\section{References}

1. Boyce WH. Am J Med. 1968:45:673-83.

2. Boyce WH, Garvey FK. J Urol. 1956;76:213-27.

3. Finlayson B, Vermeulen CW, Stewart EJ. J Urol. 1961;86:355-63.

4. Evan AP, Coe FL, Lingeman JE, Shao Y, Sommer AJ, Bledsoe SB, Anderson, J. C., et al. Anat Rec (Hoboken). 2007;290:1315-23.

5. Williams Jr JC, Zarse CA, Jackson ME, Witzmann FA, McAteer JA. J Endourol. 2006:20:560-4.

6. Boonla C, Tosukhowong P, Spittau B, Schlosser A, Pimratana C, Krieglstein K Clin Chim Acta. 2014:429:81-9.

7. Canales BK, Anderson L, Higgins L, Ensrud-Bowlin K, Roberts KP, Wu B, Kim IW, et al. Urology. 2010;76(1017):e1013-1020.

8. Canales BK, Anderson L, Higgins L, Frethem C, Ressler A, Kim IW, Monga, M. Urol Res. 2009;37:323-9.

9. Canales BK, Anderson L, Higgins L, Slaton J, Roberts KP, Liu N, Monga MJ. Endourol. 2008;22:1161-7.

10. Jou YC, Fang CY, Chen SY, Chen FH, Cheng MC, Shen CH, Liao LW, et al. Urology. 2012;80:260-6.

11. Kaneko K, Kobayashi R, Yasuda M, Izumi Y, Yamanobe T, Shimizu T. Int J Urol. 2012:19:765-72.

12. Kaneko K, Matsuta Y, Moriyama M, Yasuda M, Chishima N, Yamaoka N, Fukuuchi T, et al. Int J Urol. 2014;21:341-6.

13. Kaneko K, Yoshida N, Okazaki K, Yamanobe T, Yamaoka N, Yasuda M, Ogata N, et al. Nucleosides Nucleotides Nucleic Acids. 2011:30:1072-6.

14. Merchant ML, Cummins TD, Wilkey DW, Salyer SA, Powell DW, Klein JB, Lederer ED. Am J Physiol Renal Physiol. 2008;295:F1254-1258.

15. Thurgood LA, Wang T, Chataway TK, Ryall RL. J Proteome Res. 2010;9:4745-57.

16. Thurgood LA, Ryall RL. J Proteome Res. 2010;9:5402-12.

17. Okumura N, Tsujihata M, Momohara C, Yoshioka I, Suto K, Nonomura N, et al. PLoS One. 2013;8, e68624.

18. Valente KN, Choe LH, Lenhoff AM, Lee KH. Electrophoresis. 2012;33:1947-57.

19. Michalski A, Cox J, Mann M. J Proteome Res. 2011;10:1785-93.

20. Wisniewski JR, Zougman A, Nagaraj N, Mann M. Nat Meth. 2009;6:359-62.

21. Daudon M, Bader CA, Jungers P. Scanning Microsc. 1993;7:1081-106

22. Lai X, Wang L, Tang H, Witzmann FA. J Proteome Res. 2011;10:4799-812.

23. Lai $X$, Wang L, Witzmann FA. Int J Proteomics. 2013;2013:756039.

24. Liu JD, Liu JJ, Yuan JH, Tao GH, Wu DS, Yang XF, et al. Toxicol Lett. 2012:212:307-14

25. Skinnider BF, Folpe AL, Hennigar RA, Lim SD, Cohen C, Tamboli $P$, et al. Am J Surg Pathol. 2005:29:747-54.

26. Xie L, Weichel B, Ohm JE, Zhang K. BMC Syst Biol. 2011:5 Suppl 3:S4

27. Uhlen M, Fagerberg L, Hallstrom BM, Lindskog C, Oksvold P, Mardinoglu A, et al. Science. 2015;347:1260419.

28. Thongboonkerd V, McLeish KR, Arthur JM, Klein JB. Kidney Int. 2002;62:1461-9

29. Morse RM, Resnick MI. J Urol. 1988;139:869-73.

30. Boyce WH, King Jr JS. J Urol. 1959;81:351-65.

31. Stoller ML, Meng MV, Abrahams HM, Kane JP. J Urol. 2004:171:1920-4.

32. Boyce WH, Sulkin NM. J Clin Invest. 1956;35:1067-79.

33. Giachelli CM, Steitz S. Matrix Biol. 2000;19:615-22.

34. Kirsch T. Connect Tissue Res. 2012;53:438-45.

35. Eguchi Y, Inoue M, lida S, Matsuoka K, Noda S. Kurume Med J. 2002:49:99-107.

36. Khan SR. J Urology. 2013;189:803-11.

37. Khan SR, Kok DJ. Front Biosci. 2004;9:1450-82.

38. Williams Jr JC, MCAteer JA, Evan AP, Lingeman JE. Urol Res. 2010;38:477-84.

39. Bradford MM. Anal Biochem. 1976;72:248-54.

40. Hale JE, Butler JP, Gelfanova V, You J-S, Knierman MD. Anal Biochem. 2004:333:174-81.

41. Keller A, Nesvizhskii Al, Kolker E, Aebersold R. Anal Chem. 2002;74:5383-92. 
42. Nesvishskii Al, Keller A, Kolker E, Aebersold R. Anal Chem. 2003;75:4646-58

43. Elias JE, Gygi SP. Nat Methods. 2007;4:207-14.

44. Monroe ME, Shaw JL, Daly DS, Adkins JN, Smith RD. Comput Biol Chem. 2008;32:215-7.

45. Gasteiger E, Hoogland C, Gattiker A, Duvaud S, Wilkins MR, Appel RD. Bairoch, A. In: Walker JM, editor. The Proteomics Protocols Handbook. Totowa, NJ: Humana Press; 2005. p. 571-607.

46. Kim MS, Pinto SM, Getnet D, Nirujogi RS, Manda SS, Chaerkady R, et al. Nature. 2014;509:575-81.

47. Stelzer G, Dalah I, Stein TI, Satanower Y, Rosen N, Nativ N, et al. Hum Genomics. 2011;5:709-17.

48. Ashburner M, Ball CA, Blake JA, Botstein D, Butler H, Cherry JM, et al. Nat Genet. 2000;25:25-9.

Submit your next manuscript to BioMed Central and we will help you at every step:

- We accept pre-submission inquiries

- Our selector tool helps you to find the most relevant journal

- We provide round the clock customer support

- Convenient online submission

- Thorough peer review

- Inclusion in PubMed and all major indexing services

- Maximum visibility for your research

Submit your manuscript at www.biomedcentral.com/submit
Biomed Central 